嗅床技術

論文受付

2019 年 12 月 17 日

論文受理

2020 年 6 月 30 日

Code No. 333

\section{深層学習を用いた PET 画像の減弱補正を目的とした 疑似 CT 画像の作成}

\author{
福井亮平 ${ }^{1}$ 藤井 進 $^{2}$ 二宮宏樹 ${ }^{2}$ 藤原泰裕 $^{2} \quad$ 井田智延 $^{2}$
}

\author{
${ }^{1}$ 鳥取大学医学部附属病院放射線部 (現 岡山大学大学院保健学研究科放射線技術科学分野) \\ 2 鳥取大学医学部附属病院放射線部
}

\section{緒 言}

陽電子断層撮影法 (positron emission tomography: PET) は，さまざまな疾患の検出，診断に有用な検查 法である ${ }^{1 \sim 3)}$ 。また，保険適用疾患や放射性医薬品の 追加もあり，検査対象を続々と増やしている。特に， 2-deoxy-2-[F-18]fluoro-D-glucose (FDG)を用いた FDGPETは，全身検索を目的として最も普及している検 查である。しかし，PET画像において身体深部で発 生した消滅放射線の吸収による信号值の低下は病変の 検出能にも影響を与えるため ${ }^{4}$, 種々の減弱補正法が
検討されてきだ,6). 特に, computed tomography (CT) から得た画像を用いた手法 (CTAC) は, 短時間 かつ高精度な減弱補正を実現することで, 診断能の向 上にも寄与している7)。しかし, CT を撮影するため患 者被ばくの増大が懸念されている. FDG-PET/CT 検査による患者の被ばくについてはさまざまな文献に より報告されている。例えば，Kwon らによる報告で は FDG 薬剂により $5.89 \mathrm{mSv} ， \mathrm{CT}$ により $6.26 \mathrm{mSv}$ と されている8)。また，国内のガイドラインでは，FDG 薬剤により $3.5 \mathrm{mSv}$ ，減弱補正用 CTにより 1.4-3.5

\title{
Generation of the Pseudo CT Image Based on the Deep Learning Technique Aimed for the Attenuation Correction of the PET Image
}

Ryohei Fukui, ${ }^{1 *}$ Susumu Fujii, ${ }^{2}$ Hiroki Ninomiya, ${ }^{2}$ Yasuhiro Fujiwara, ${ }^{2}$ and Tomonobu Ida ${ }^{2}$

${ }^{1}$ Division of Clinical Radiology, Tottori University Hospital (Current address: Department of Radiological Technology, Graduate School of Health Sciences, Okayama University)

${ }^{2}$ Division of Clinical Radiology, Tottori University Hospital

Received December 17, 2019: Revision accepted June 30, 2020

Code No. 333

\section{Summary}

Computed tomography (CT) is used for the attenuation correction (AC) of [F-18] fluoro-deoxy-glucose positron emission tomography (PET) image. However, acquisition of a CT image for this purpose requires increasing the radiation dose of the patient. To generate a pseudo-image, a generative adversarial network (GAN) based on deep learning is adopted. The purpose of this study was to generate a pseudo-CT image, using a GAN, for the $\mathrm{AC}$ of the PET image, with the aim of reducing the dose of the patient. A set of approximately 15,000 no-AC PET and CT images was used as the training sample, and the CycleGAN was employed as the image generation model. The training samples were inputted in the CycleGAN, and the hyperparameters, i.e., the learning rate, batch size, and number of epochs were set to $0.0001,1$, and 300, respectively. A pseudo-PET image was obtained using a pseudo-CT image, which was used for the AC of the no-AC PET image. The coefficient of similarity between the real and generated pseudo-images was estimated using the peak signal-to-noise ratio (PSNR), the structural similarity (SSIM), and the dice similarity coefficient (DSC). The average values of PSNR, SSIM, and DSC of the pseudo-CT were $31.0 \mathrm{~dB}, 0.87$, and 0.89 , and those of the pseudo-PET were $35.9 \mathrm{~dB}, 0.90$, and 0.95 , respectively. The AC for the whole-body PET image could be accomplished using the pseudo-CT image generated via the GAN. The proposed method would be established as the CT-less PET/CT examination.

Key words: PET, attenuation correction, deep learning, pseudo CT, generative adversarial network (GAN)

*Corresponding author 
$\mathrm{mSv}$ (読影を目的とする場合は $10 \mathrm{mSv}$ 以上)とされて いる99. したがって，CTによる被ばくを低減すること は, PET/CT 検査全体の被ばく低減に直結している。

近年, 人工知能分野の研究を飛躍的に向上させた技 術に深層学習がある。従来, 人間が与えていた入力画 像の特徵量をコンピュータが自動的に学習すること で, 学習効率を大幅に向上させた. 現在, 医療分野に おいても深層学習をべースとしたさまざまな研究や商 品が生み出されている ${ }^{10,11)}$ ，深層学習に扔いて注目さ れているアイデアに敵対的生成ネットワーク (Generative Adversarial Networks: GAN)がある ${ }^{12}$. GAN は，偽のデー夕を生成する生成器 (generator) と, そのデー夕の真贋を判定する識別器 (discriminator) という二つのモデルをもっている。，それぞれの モデルが相互研鑽して学習を進めることで, 最終的に は generatorにより教師画像の特徵をもった画像が生 成できるようになる，GAN を用いることで疑似的な CT 画像を作成し，これを $\mathrm{PET}$ 画像の減弱補正に用 いた報告はある ${ }^{13 \sim 15)}$. しかし, magnetic resonance imaging(MRI) 画像をべースにした報告や, 対象が頭 部に限定された報告が多く, 全身を対象とした報告は 限られている ${ }^{16)}$. 本研究では，減弱補正を目的とした CT 撮影を省略することで患者被ばくを低減できる PET 検査を目指し，疑似的な CT 画像 (pseudo_CT) による減弱補正が可能か検討した。

\section{1. 方 法}

\section{1-1 使用機器および試料}

\section{1-1-1 PET/CT 装置および収集条件}

PET/CT 装置は Discovery MI-DR (GE Healthcare, Milwaukee, WI, USA) を使用した。本装置はシンチ レータにLYSO $\left(\mathrm{Lu}_{2 \cdot \mathrm{x}} \mathrm{Y}_{\mathrm{X}} \mathrm{SiO}_{5}\right.$ : Ce)を採用し，また 64 列 CT を搭載している，患者は 6 時間以上の絶食後, FDG を静注投与 $(2-5 \mathrm{MBq} / \mathrm{kg})$ した. 60 分の安静待 機の後, まず CT 撮影を行った. CT の撮影条件は, 管電圧 $120 \mathrm{kV}$, 管電流は自動露出機構を使用 (最大管 電流 $500 \mathrm{~mA}$ ), 設定 SD10.0，およびピッチファクタ は 1.375 とした。 その後, CT 撮影と同じ範囲を 3DPET 収集を行った. PET の収集条件は $2 \mathrm{~min} / 1$ bed とし，スライスオーバーラップは 11 スライスとした

\section{1-1-2 PET 画像の再構成条件}

後述する深層学習の学習データとして減弱補正等が 付加されていないPET 画像(noac_PET) を取得した. noac_PET は ordered subset expectation maximization(OSEM) 法に time-of-flight (TOF) 情報を組み込ん だ再構成を用いた。ただし, point-spread-function
(PSF) 補正は付加されていない. Iterationは2, subsetは24を選択した。CT 画像による減弱補正等を臨 床条件と同様に付加したPET 画像(real_PET) も出力 した. real_PETは block sequential regularized expectation maximization (BSREM) 法をべースにした GE Healthcare 社独自の再構成手法である Q.Clear を 使用した。 $\beta$ は 650 とした。また, TOF および PSF 補正は付加した。なお, noac_PETおよびreal_PET 画像の field of view(FOV)は 600×600 mm，マトリクス サイズは 192×192 pixel, スライス厚は 3.75 mm である.

\section{1-1-3 CT 画像の再構成条件}

深層学習の学習データとなる CT 画像 (real_CT)の 再構成には逐次近似応用再構成法(ASiR50\%)を用い た. 再構成関数は GE Healthcare 社の軟部条件用関数 であるStndを使用した。また，FOVは600×600 mm，マトリクスサイズは 512×512 pixel である。 ス ライス厚はPET 画像と同様, $3.75 \mathrm{~mm}$ である。 なお, 上述した PET およびCT の撮影条件および再構成条 件は当院の臨床で実際に用いている設定值である.

\section{1-1-4 学習・評価・試験データ}

学習データとなる noac_PET 画像抒よび real_CT 画像は, 2019 年 5 月から 6 月に当院で診療目的に $\mathrm{PET} / \mathrm{CT}$ 検査を施行した患者デー夕を使用した。こ のうち, 撮影範囲が頭部から骨盤部であり，極端な異 常集積や異常像のない一般的な体格をもつ 50 症例 (男 性 34 例, 女性 16 例, 平均年齢 $72 \pm 16$ 歳, 平均身長 $159.4 \pm 6.0 \mathrm{~cm}$, 平均体重 $52.0 \pm 12 \mathrm{~kg}$ ) を選択した。 ただ し, これらの症例は正常症例ではなく, 固形がん(術 前，または術後)などの既往がある症例である。平均 の FDG 投与量は $230.2 \mathrm{MBq}$ であった。 1 症例から noac_PET およびreal_CT 画像は，それぞれ約 300 枚 程度取得できるため，学習データセットはそれぞれ約 15000 枚を用意した。このうち，9 割を training 用，1 割を validation 用として使用した。また，作成した pseudo_CT と real_CT 間の類似度を評価するために 1 症例, 加えて, 異常集積などの目視確認を目的とし て 4 症例を, 上述の 50 症例とは別に用意した。画像 データは匿名化して, Digital Imaging and Communication in Medicine (DICOM) 画像として出力した。な お, 患者画像の使用については, 事前に鳥取大学医学 部倫理審査委員会の承諾を得た。

\section{1-1-5 開発環境}

深層学習を開発，また実行するコンピュータの OS は Windows 10 Home 64 ビット（日本マイクロソフト, 東京)である。CPU は Core i7-7820X $3.6 \mathrm{GHz}$ (Intel Corporation, Santa Clara, CA, USA), GPU は GeForce 


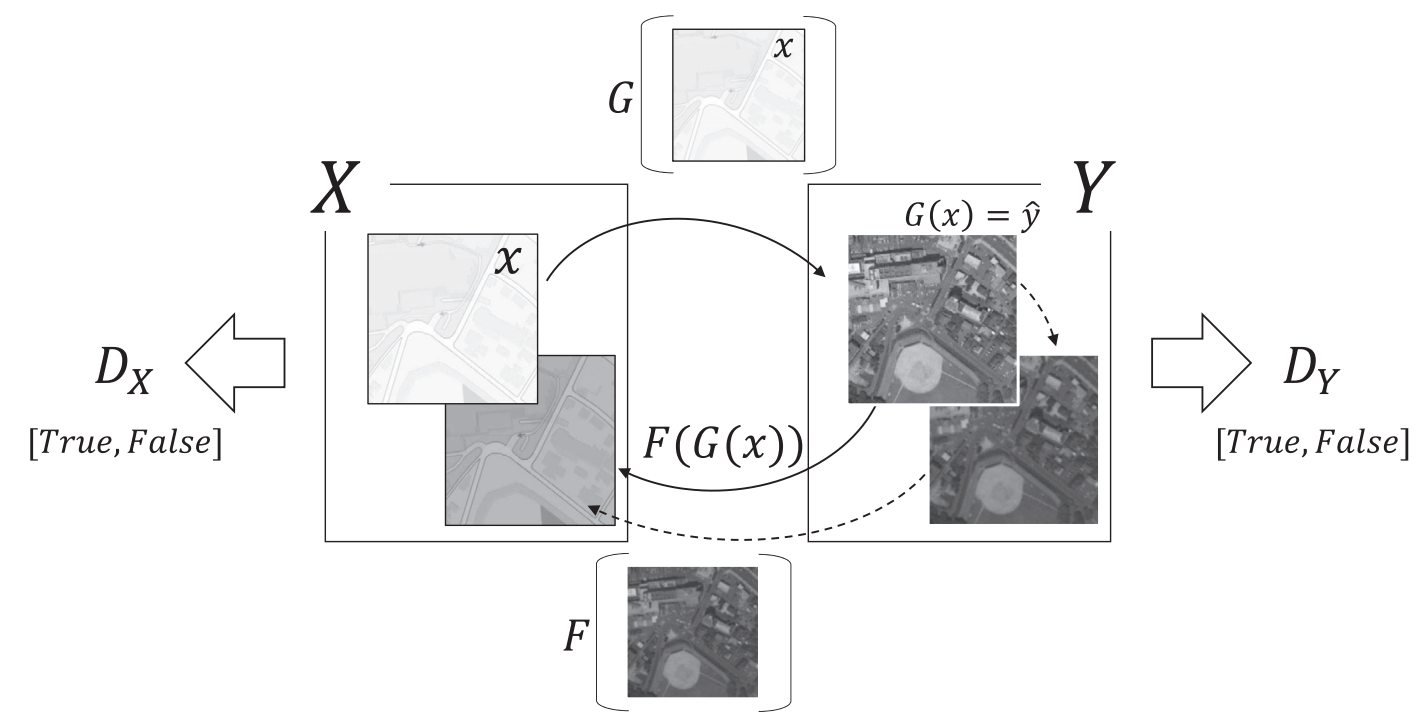

Fig. 1 Schematic of the CycleGAN.

The CycleGAN contains two mapping functions $G(X$-to- $Y)$ and $F(Y$-to- $X)$, and associated adversarial discriminators $D_{X}$ and $D_{Y}$.

GTX 1080Ti (NVIDIA Corporation, Santa Clara, CA, USA)を使用した。物理メモリは $128 \mathrm{~GB}(16 \mathrm{~GB} \times 8)$, ストレージはSSD $1 \mathrm{~TB}, \mathrm{CPU}$ と GPU の排熱には水 冷を採用した。ディストリビューションとして Anaconda(Anaconda Inc., Austin, TX, USA)をインス トールした。深層学習の開発言語にはPython 3.6 (Python Software Foundation, Wilmington, DE, USA) を採用し，GANの実行環境として Jupyter notebook (Project Jupyter), 深層学習の開発用フレームワーク として PyTorch (Facebook Inc., Menlo Park, CA, USA）を採用した。DICOM 画像の表示, 編集には ImageJ(NIH)を使用した，加えて，画像ヘッダの編集 は Visual Studio 2015(日本マイクロソフト)を使用し C 言語ベースで行った。

\section{1-2 GAN}

GAN は機械学習技術の一つで, 同時に訓練される 二つのモデル, generator と discriminator から成 る ${ }^{17)}$. Generatorの目標は, 学習データの特徵をより 反映したサンプルを作成し，そのサンプルが学習デー 夕と見分けがつかないようにすることである。また， discriminator は特定のサンプルが本物 (学習データの サンプル)か，それとも generator が作成した偽物か 判断することを目標としている. Generator は, discriminator による真偽の判断結果をフィードバックす ることで改善され，また discriminator は自身の予測 がどの程度正当に近いか，といった情報をもとに改善 される，このように，二つのモデルが絶えず相手を出
し抜こうと競争的，つまり敵対的に動作することで ネットワーク全体が強化され, 最終的に本物と見分け ることが困難な画像が生成可能となる。

\section{1-3 CycleGAN}

現在, 対象や目的に応じてさまざまな改良が加えら れた GAN が存在する ${ }^{18-20)}$. その中でも CycleGAN は，画像変換を行う GAN の中で注目されているモデ ルである ${ }^{21)}$. CycleGAN のモデルを簡易的に Fig. 1 に 示した。オリジナルの GAN には 1 組の generator と discriminator が存在するが, CycleGAN では 2 組存在 する. Generator は Residual Network (ResNet) ${ }^{22)}$, Discriminator は Convolutional Neural Network $(\mathrm{CNN})$ で構成される。二つの Generator を用いて学 習データセット間を相互に変換(例えば PET から CT, または CT から PET) し, 生成された画像の真贋 を二つの discriminatorで評価を行う。この結果は 各々の generator と discriminatorに逆伝搬され, 学 習率 $(\mathrm{Lr})$ に応じた重みの更新が行われる。一連の学 習が繰り返し回数 (epoch) 分だけ行われることで, 結 果としてPET 画像から CT 画像へ変換するモデルが 完成する。本研究では, Lr は 0.0001, epoch は 100, 300, 900 の 3 種類, バッチサイズも 1, 32, 64 の 3 種 類, 最適化アルゴリズムは Adaptive Moment Estimation(Adam)を使用して学習を行った。また, Adversarial Loss 㧍よび Cycle Consistency Loss のバラン スは重み付けを行わず $1: 1$ とした。 


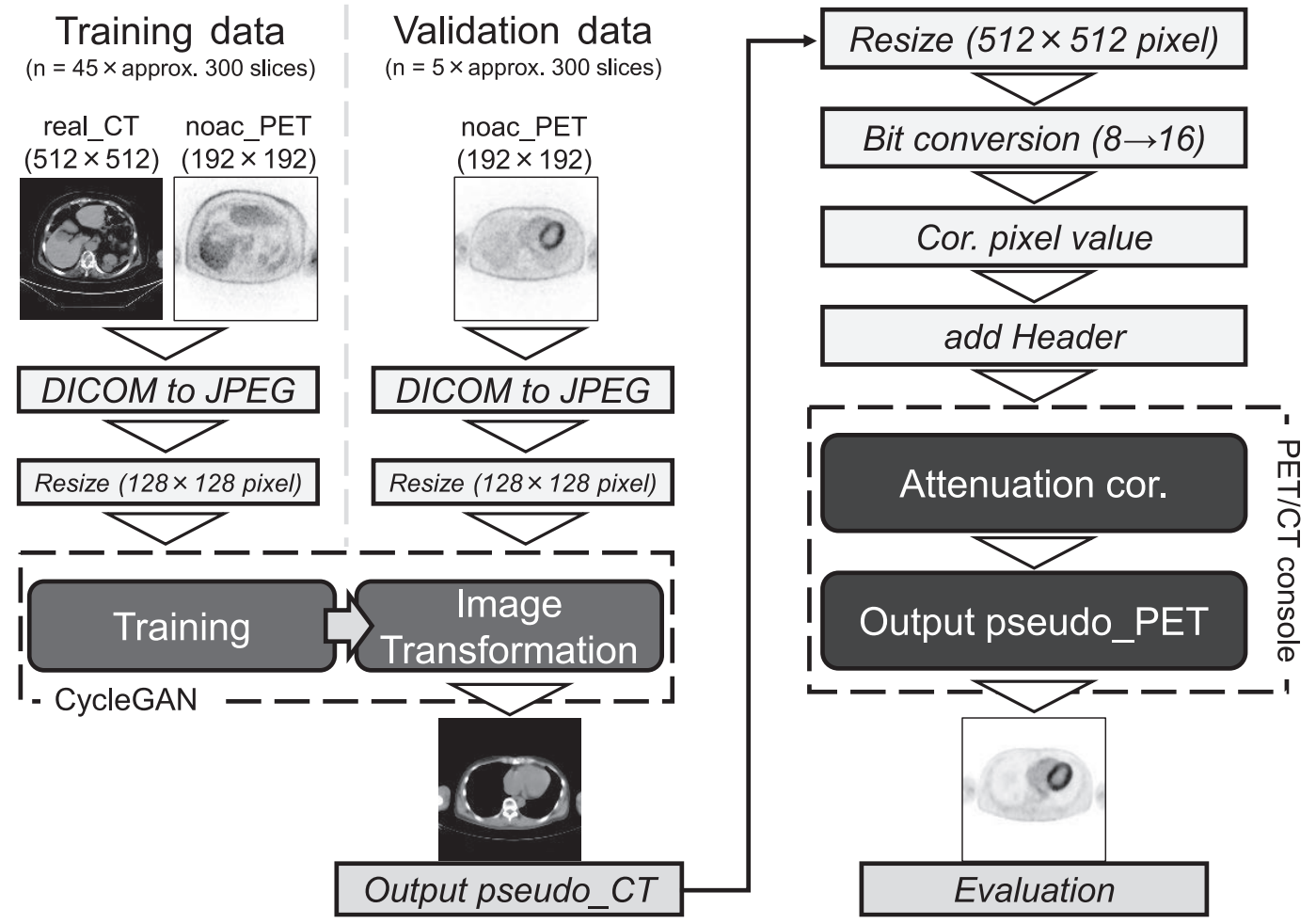

Fig. 2 Outline of this study from the input phase of the training samples to the acquisition phase of the pseudo_PET. The training samples have been resized. The attenuation correction was performed on the console of the $\mathrm{PET} / \mathrm{CT}$ equipment.

\section{1-4アウトライン}

作成した pseudo_CT 画像を用いて noac_PET に減 弱補正を行うまでのアウトラインを Fig. 2 に示した.

取得したnoac_PET 䇽よびreal_CT 画像はマトリ クスサイズが異なるため, まずDICOM から JPEGへ 変換し, real_CT は 192×192 pixelへダウンサイジング した。PETやCT 撮影時の FOVは体に対して非常に 大きく, 空気だけの領域が多いためか, 192×192 pixel のマトリクスサイズでそのまま学習を進めてもよい結 果が得られなかった。そこで本研究では，192×192 pixel の元画像と同中心をもつ $128 \times 128$ pixel の region of interest(ROI) を設定し, 周囲をトリミングするこ とで, 極力空気の領域が少ない画像を作成して, 学習 用データとした，作成したデータを入力データとして CycleGANにより学習を行い, 学習結果をnoac_PET 画像に反映することで, pseudo_CT を得た。

最終的に, PET/CT 装置本体のコンソールに作成 したpseudo_CT 画像を戻すことで減弱補正を行うこ とを考えた。しかし，128×128 pixel で出力された pseudo_CT を直接コンソールに戻すことはできない ため, 画像データとして real_CT と同様になるように 画像の調整を行った。まず, real_CT と同じ $512 \times 512$ pixel ヘマトリクスサイズを変更し，また16-bitへ階
調変換を行った。CycleGANにより noac_PET 画像 から作成された pseudo_CT 画像は CT 值ではなくピ クセル值となっている。 そこで DICOM Tag の Rescale Intercept $\left(R_{\text {Inter }}\right)$ と Rescale Slope $\left(R_{\text {Slope }}\right)$ を用いて 次式よりピクセル值 $(P V)$ から CT 值へ変換を行った.

$C T$ value $=\left(P V \times R_{\text {slope }}\right)+R_{\text {Inter }}$

加えて, pseudo_CT は DICOM ヘッダを持たない ため, real_CT の DICOM ヘッダを pseudo_CT の ヘッダとして付加し，このデータセットをコンソール へ戻すことでnoac_PET の減弱補正を行った，noac_ PET の減弱補正には real_PET 同様，Q.Clear を使用 し，その他の設定条件もreal_PETと同様とした。一 連の過程により pseudo_CTを用いて減弱補正された PET 画像をpseudo_PET としてコンソールから出力 した.

\section{1-5 類似度の評価指標}

real_CT と pseudo_CT, またreal_CT から減弱補 正を行ったreal_PETに対し，noac_PETおよび pseudo_PET との類似度を算出することで, 減弱補正 の可否を検討した，類似度の指標には Peak Signal to Noise Ratio(PSNR), Structural Similarity (SSIM) と, 
Dice 係数 (Dice similarity coefficient, DSC) を用い た $^{14,16,23)}$.

PSNR は次式より算出される。

$P S N R=10 \log _{10} \frac{P V_{\max }^{2}}{M S E}$

ここで, $P V_{\text {max }}$ はその画像が取り得る最大ピクセル 值である。また，MSEは平均二乗誤差であり，

$M S E=\frac{\sum\left(i_{x, y}-j_{x, y}\right)^{2}}{M}$

で表される．ここで， $i_{x, y}$ および $j_{x, y}$ は同一座標におけ るピクセル值, $M$ は総ピクセル数である. PSNRの単 位は $\mathrm{dB}$ であり，值が大きいほど両画像が類似してい ることを表す。

SSIM は次式より算出される.

$\mathrm{SSIM}=\frac{\left(2 \mu_{x} \mu_{y}+C_{1}\right)\left(\sigma_{x y}+C_{2}\right)}{\left(\mu_{x}^{2}+\mu_{y}^{2}+C_{1}\right)\left(\sigma_{x}^{2}+\sigma_{y}^{2}+C_{2}\right)}$

ここで, $\mu_{x}$ および $\mu_{y}$ は画像の平均ピクセル值, $\sigma_{x}$ お よび $\sigma_{y}$ は画像の標準偏差, $\sigma_{x y}$ は共分散である。また, $C_{1}$ および $C_{2}$ は補正係数で,

$C_{1}=\left(0.01 \times P V_{\text {max }}\right)^{2}$

$C_{2}=\left(0.03 \times P V_{\text {max }}\right)^{2}$

である。ただし， $0 \leq S S I M \leq 1.0$ であり，算出される SSIM が 1.0 に近いほど 2 画像が類似していることを 表す.

DSC は次式により算出される.

$\mathrm{DSC}=\frac{2 \times N_{(x \cap y)}}{N_{x}+N_{y}}$

ここで， $N_{x}$ および $N_{y}$ は, 患者の身体が存在する領域 のピクセル数である。身体とそれ以外の領域との閾值 処理には大津の二值化を使用して, 領域識別を行っ $た^{24)}$ 。また， $N_{(x \cap y)}$ は両画像間で同座標に身体が存在 するピクセル数(つまり論理積)である. SSIM と同様, DSC も $0 \leq \mathrm{DSC} \leq 1.0$ の值を取り，算出される DSC が 1.0 に近いほど両画像が類似していることを表す。

\section{2. 結 果}

\section{2-1 pseudo_CTの作成}

学習したCycleGAN により pseudo_CTを作成し た。検証用に 1 症例を選択したが, この症例は training 用および validation 用のデータセットには含まれ
ていない. 検証用の症例は50 代の男性(肺がんの既 往, 身長 $179 \mathrm{~cm}$, 体重 $65 \mathrm{~kg}$, FDG $300 \mathrm{MBq}$ 投与, 安 静 1 時間後の撮影)である. Figure 3 に各 epoch で作 成したpseudo_CTを示した。また， real_CTと epoch 300 の pseudo_CT 画像との差分画像も示した. Figure 4 には epoch を100, 300 および 900 に設定し て作成したpseudo_CTをreal_CTと比較した PSNR, SSIM およびDSC の結果を示した。 epoch 300 におけるPSNR の平均值は $31.0 \mathrm{~dB}$ であった。また, SSIM と DSC の平均值はそれぞれ $0.87,0.89$ であっ た. epoch 100 で作成したpseudo_CTは, real_CTと 比較して明らかに形態的情報が劣化した画像が生成さ れており，各指標も epoch 300 に比べ低下した。ま た, epoch 900 で作成したpseudo_CTは, 体幹部につ いては epoch 300 と比して視覚的な差は認められな かったが, 頭頸部についてはさざ波状のアーチファク トが出現した，各指標についても epoch 300 と比べ頭 頚部で低值となった。また，バッチサイズについては 32 や 64 に設定した場合, 入力画像のスライスが変化 しても同じような画像しか出力されなくなった (Fig. 5).したがって, pseudo_CT として epoch 300, バッ チサイズ 1 で生成した画像を採用し, 以降の減弱補正 に使用した。

\section{2-2 減弱補正の適用}

pseudo_CTをPET/CT 装置のコンソール上ヘイン ポートし, 減弱補正に使用することで得た pseudo_ PETの画像を Fig. 6 に示した。 また, real_PETと pseudo_PETとの差分画像も示した. noac_PETに比 べpseudo_PETでは身体深部の信号低下が改善され， 減弱補正が適用されていることが確認できた。 real_ PET と比較したPSNA，SSIM およびDSCの結果を Fig. 7 に示した. pseudo_PETのPSNR, SSIM およ びDSCは，いずれもnoac_PET から算出した值より 高值となった. pseudo_PETのPSNR, SSIM および DSC の平均值はそれぞれ $35.9 \mathrm{~dB}, 0.90,0.95$ となっ た.しかし, pseudo_PETでは脊椎近傍など, real_ PET で集積のない箇所が高集積となる減弱補正のミ スマッチがいくつか確認された。

\section{2-3 その他の pseudo_CT}

上記の結果に示した症例以外にも, いくつかの症例 でpseudo_CTの作成を試みた。 その中で，特に注目 すべきであった症例を Fig. 8 に示す. Figure 8a は歯 冠によるアーチファクトの発生を pseudo_CTにより 低減できた症例である。 Figure 8b は, PET 画像の 


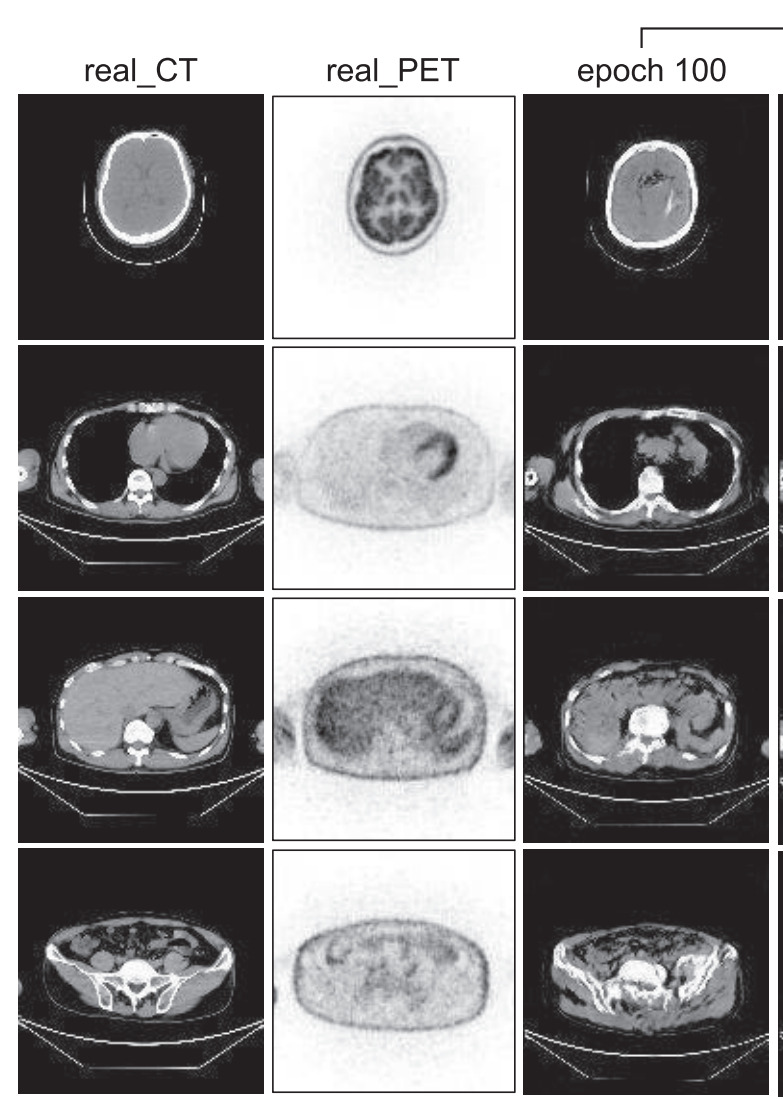

pseudo_CT

epoch 300

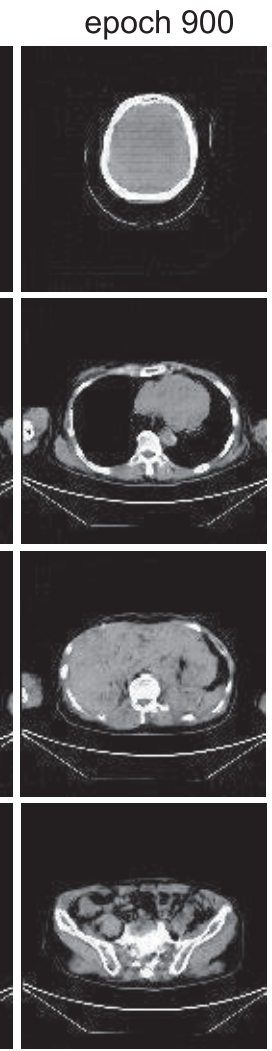

Subtraction
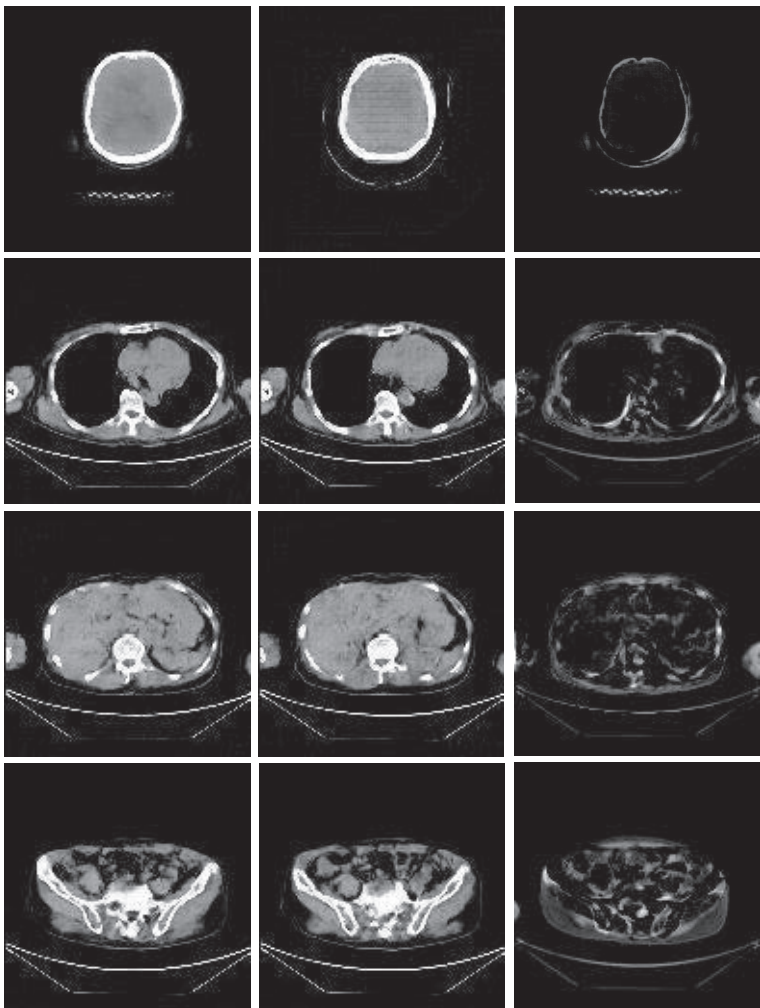

Fig. 3 The real_CT, the noac PET, and the pseudo_CT images.

(a) real_CT, (b) noac_PET, (c) pseudo_CT (epoch 100), (d) pseudo_CT (epoch 300), (e) pseudo_

a

$\mathrm{a}|\mathrm{b}| \mathrm{c}|\mathrm{d}| \mathrm{e} \mid \mathrm{f}$ CT (epoch 900), (f) subtraction images (real vs. epoch 300)

a

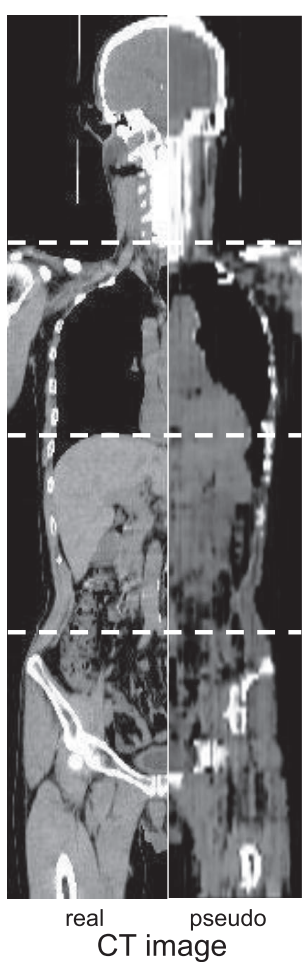

b

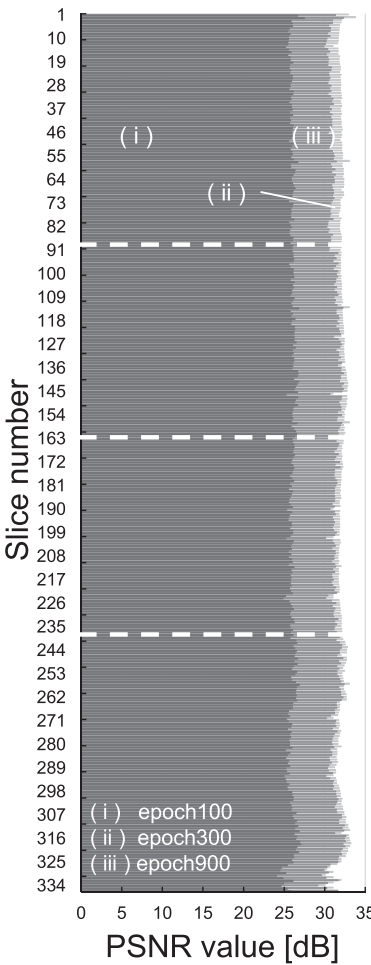

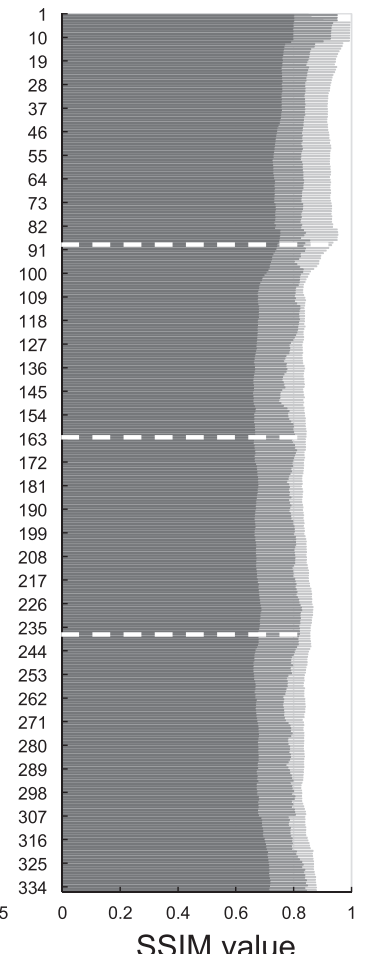

C

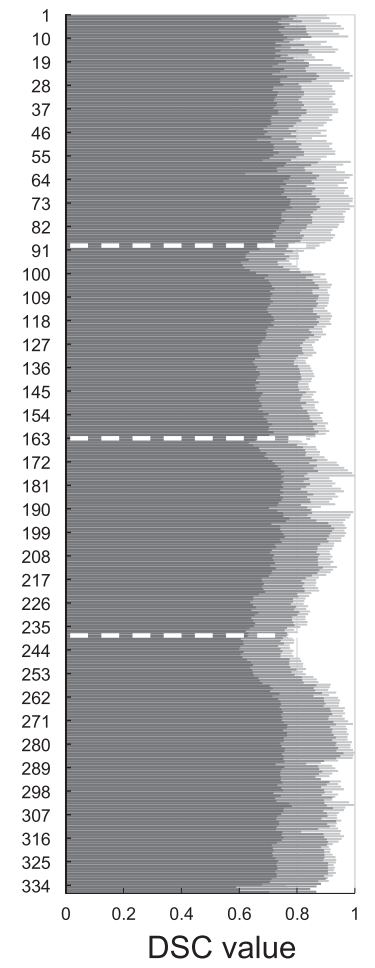

Fig. 4 Results of (a) the PSNR, (b) the SSIM and (c) the DSC estimated from the real_CT and pseudo_PET (epoch 300).

The average values of PSNR, SSIM, and DSC were $31.0 \mathrm{~dB}, 0.87$, and 0.89 , respectively. 


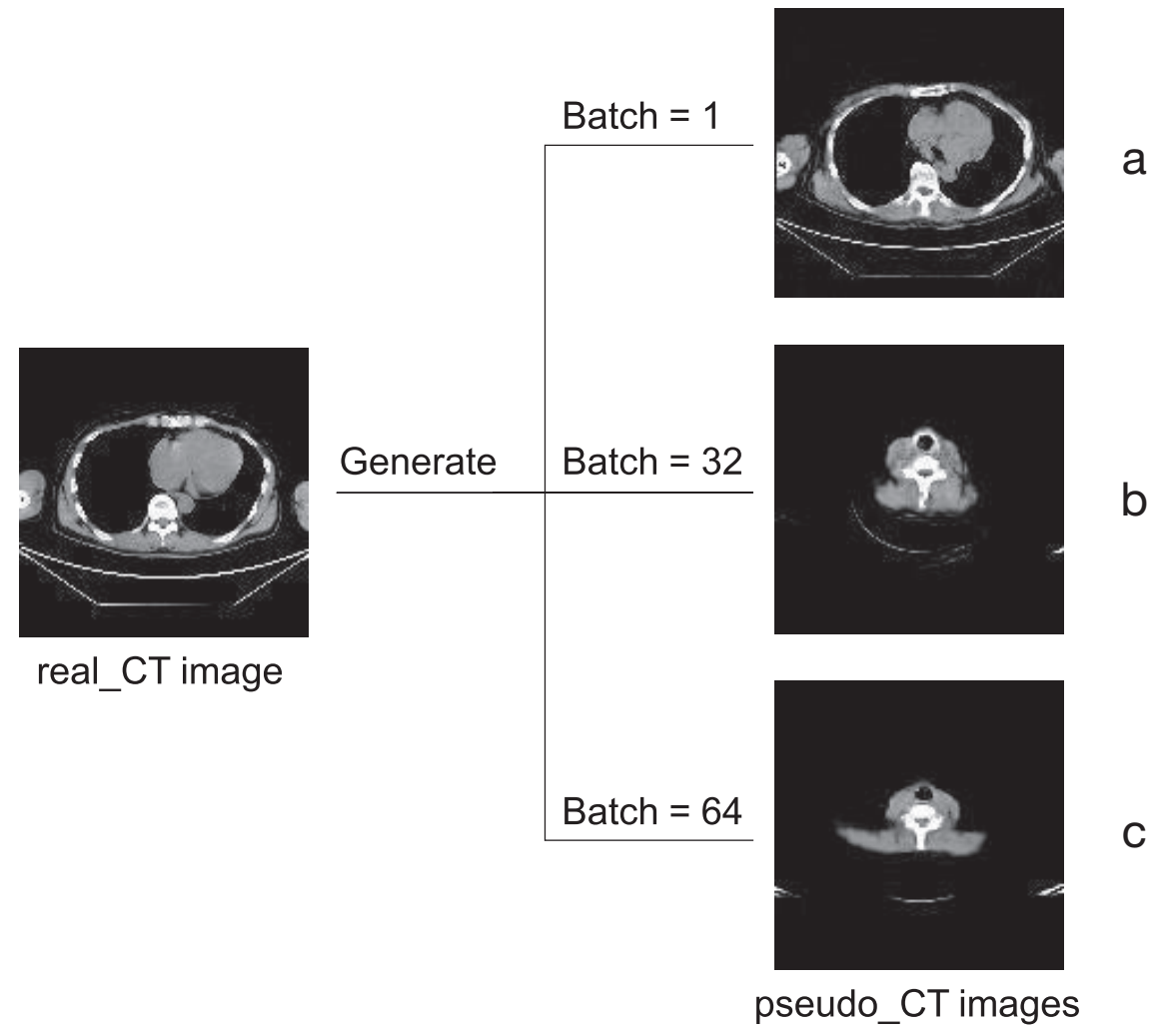

Fig. 5 The pseudo_CT images were employed a batch size of (a) 1, (b) 32, and (c) 64.
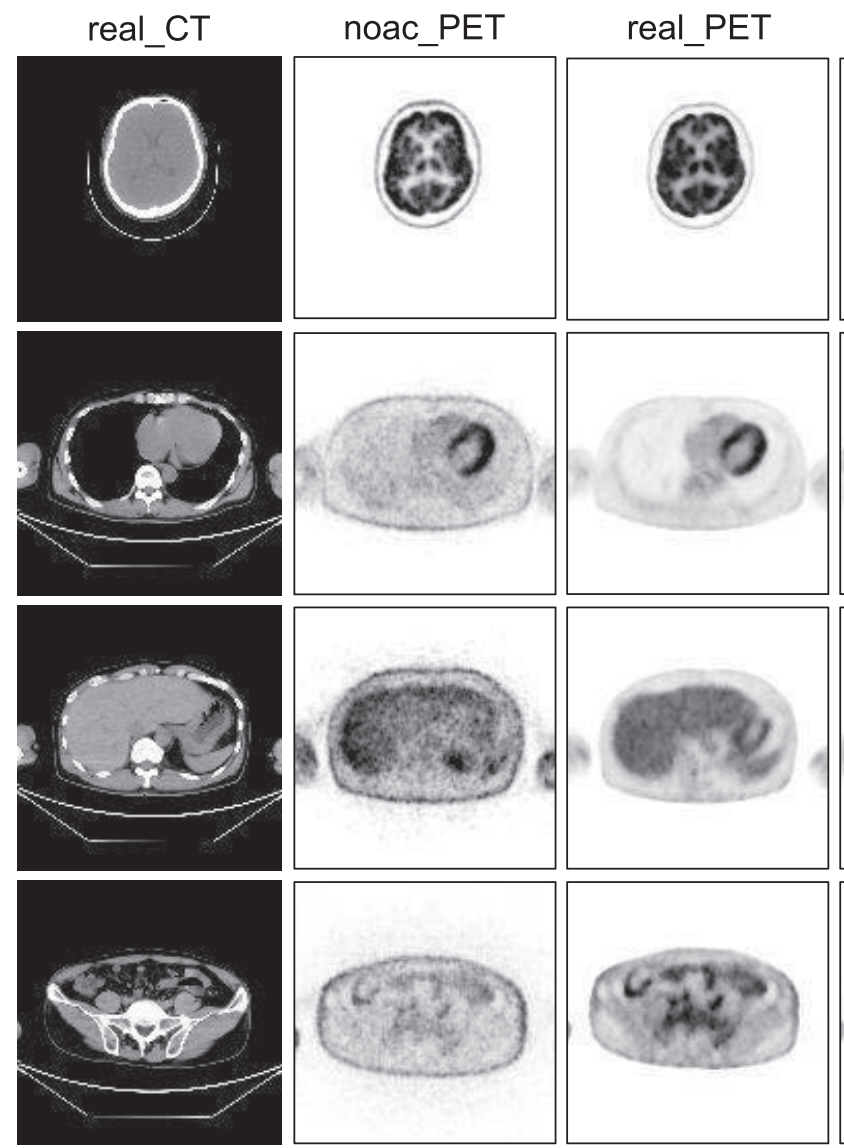

pseudo_PE

Subtraction

Fig. 6 The pseudo_PET images.

(a) real_CT, (b) noac_PET, (c) real_PET, (d) pseudo_PET, (e) subtraction images (real

a vs. pseudo_PET) 
a

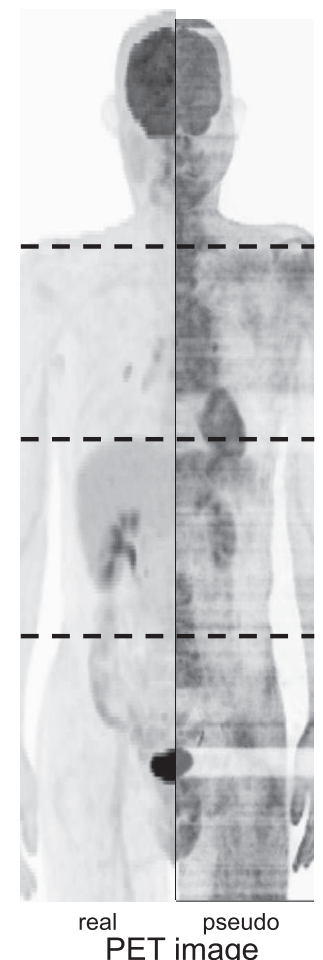

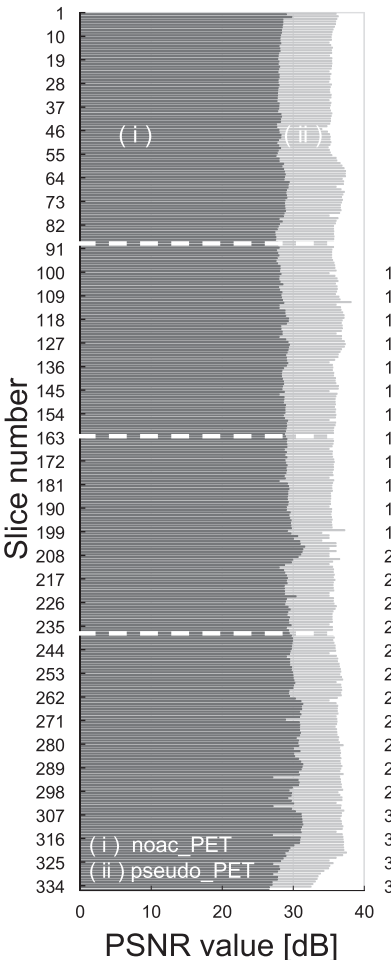

b

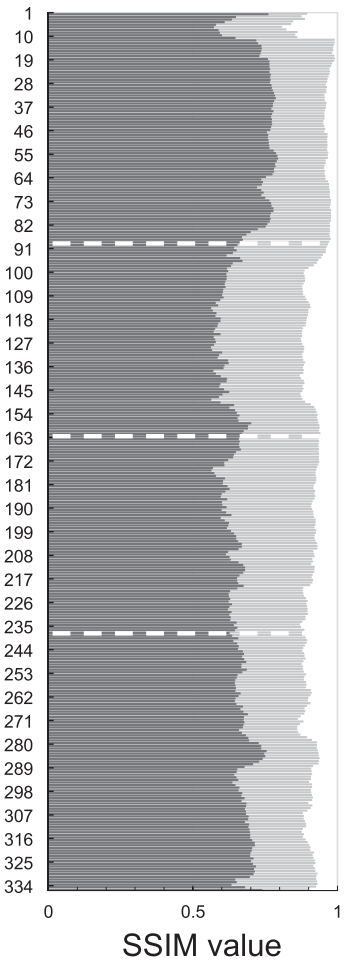

C

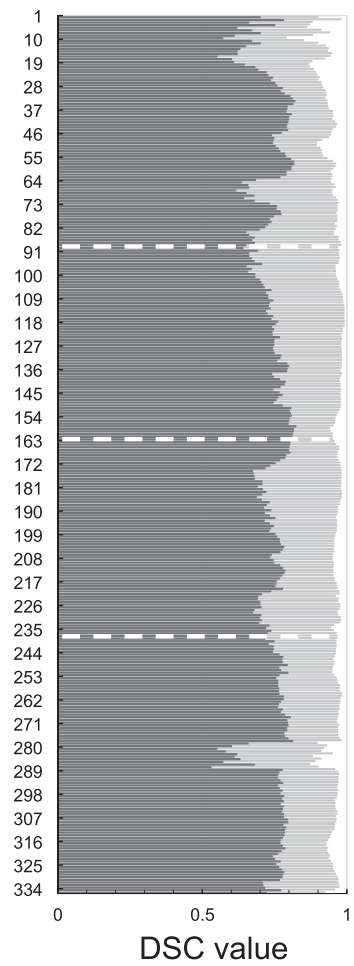

Fig. 7 Results of (a) the PSNR, (b) the SSIM, and (c) the DSC estimated from the noac_PET and pseudo_PET based on the real_PET. The average values of PSNR, SSIM, and DSC of the pseudo_PET were $35.9 \mathrm{~dB}, 0.90$, and 0.95 , respectively.
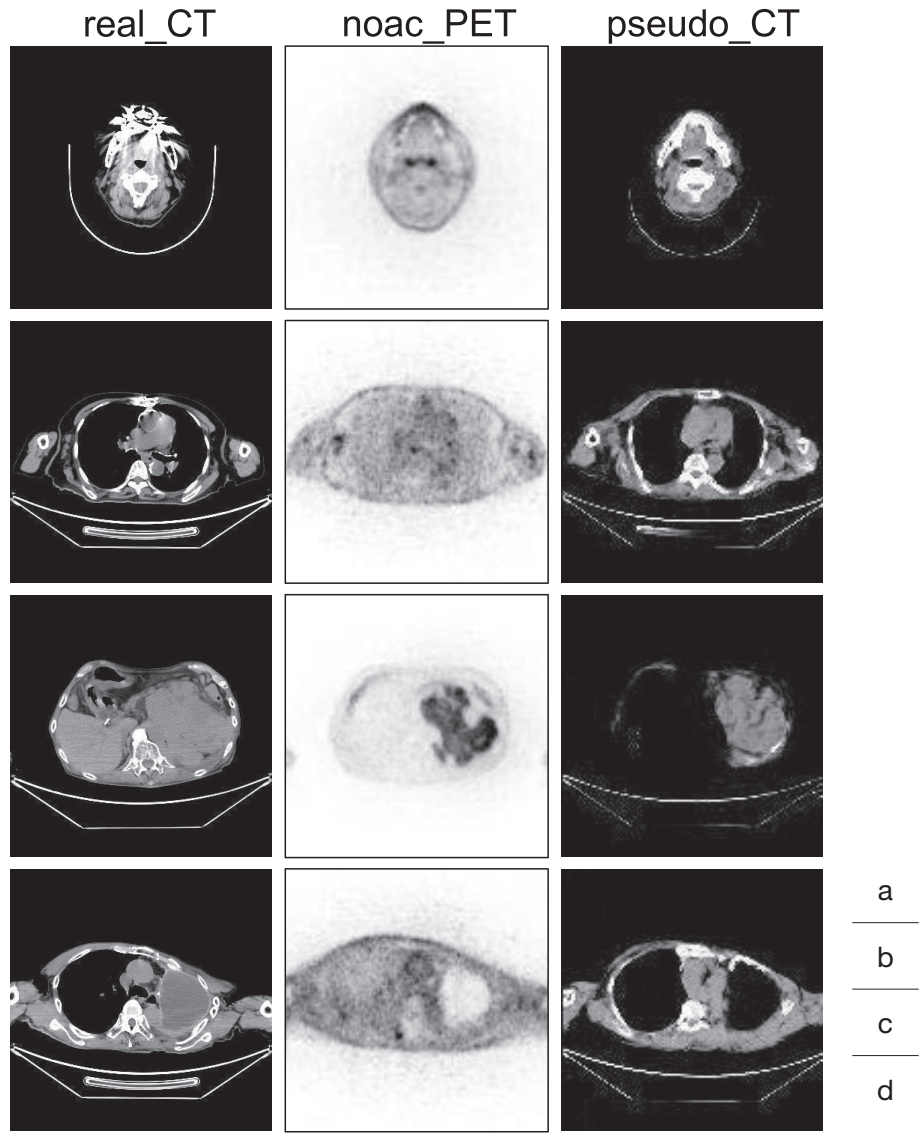

Fig. 8 Notable cases of the generated pseudo_CT image.

These cases were (a) reduced dental crown artifact, (b) not imaged calcification, (c) specific high uptake, and (d) total collapse of the left lung. 
FDG 集積をベースに pseudo_CT を作成する都合上, real_CT 上は確認できる石灰化が pseudo_CT では確 認できなかった症例である，real_CT で確認できる胸 部大動脈内側の石灰化が, pseudo_CT では確認でき なかった. Figure $8 \mathrm{c}$ は特異的な FDG の高集積症例 である. 本症例では, 高集積部以外は画像化不能で あった. Figure 8d は無気肺症例を示した. real_CT では左肺が完全に無気肺となっているが, pseudo_CT では含気のあるような画像が作成された。

\section{3. 考 察}

本研究では, CycleGANを画像生成のモデルとして 採用した. CycleGANの最大の特徵は, 学習データの 特徵が共通していれば，学習データがペアでなくても 効率的に学習できる点であり, データセットを得にくい 医用画像において大きな武器となる。 また，本研究で はバッチサイズを 1 として学習を行った。深層学習で はデータセットを複数の小さいデータセットに分け, 確率的勾配降下法を用いて学習する ${ }^{25)}$. したがって, バッチサイズは 128 や 256 など, データセットのサイ ズに応じたバッチサイズを選択することが多い．しか し, 先行研究ではバッチサイズを 1 として学習を行っ ている ${ }^{12,18,21)}$ ．実際にわれわれもバッチサイズをいく つか変更して pseudo_CT の作成を試みたが，バッチ サイズが大きくなるにつれ生成される pseudo_CTに 多様性がなくなり，いかなるnoac_PET 画像について も同じような pseudo_CT が出力されるようになっ た。これは mode collapse (画像様式の崩壊)という GAN 特有の問題である ${ }^{26)}$. したがって, 他のモデル でも同様であるが, ハイパーパラメータの設定につい ては慎重に検討する必要がある。

Epoch 数についても, 本研究では 3 種類の epoch 数 で検討した. epoch 900 で設定した場合, 体幹部の pseudo_CT については epoch 300 と比べても遜色な かったが，頭部については epoch 300 よりも劣化し た. 本検討で学習データとした全身 PET/CT 画像は 1 症例当たり 300 枚前後であった，その中で頭頸部の 占める画像枚数は 80 から 100 枚弱であったため, 学 習用のデータセットの中で胸部〜骨盤部の画像が占め る割合が多い。このような要因により, 学習回数を増 やすことで体幹部にオーバーフィッティングした学習 結果となったと考えられる。したがって，学習回数を 単純に増やすのではなく, epoch ごとに validationの データセットから画像生成するなど, 学習の推移を観 察することが肝要である。また，より学習精度を高め るために，頭頸部と体幹部を分けたデータセットで学
習することも解決策の一つだと考える. Figure 3 には 差分画像も示したが，いくつかの構造物や辺縁は差分 されず残った。この原因は pseudo_CT がnoac_PET の集積を参考にして作成されるため, real_CTに比べ pseudo_CT の構造物の大きさに多少の誤差が生じる ことや，ピクセル值を完全には再現できなかったこと に起因すると考える。

類似度の評価指標として三つの指標を算出した。 epoch 300 ではいずれの指標も高值を示した。しか し, 電子化文書の画像圧縮ガイドラインでは, PSNR が $40 \mathrm{~dB}$ 以上また SSIM が 0.98 以上で元画像と比べ た劣化が区別できない, PSNR 30-40 dB または SSIM 0.9-0.98 では拡大すれば劣化がわかる, PSNR $30 \mathrm{~dB}$ 以 下またはSSIM 0.9 以下では明らかに劣化している, とされている ${ }^{27)}$. したがって, 本研究で得られた pseudo_CTは上記基準と照らし合わせると, real_CT を代替できるほど再現できたとは言い難い。しかし， この課題はより多くの学習画像やより最適化された八 イパーパラメータの設定により克服できると考えてい るため, 本研究では各指標を試料間の相対的な值とし て捉えて評価に使用した，スライス位置で評価指標の 結果を参照すると指標間でやや異なった. PSNRは頭 部から骨盤部まで值の変化は小さかったが, SSIM と DSC は算出する部位により值が変化した，SSIM は胸 部から骨盤部でやや低下した。これは頭頸部の生成に 比べ胸部から骨盤部の構造が複雑になり, real_CT と 生成されたpseudo_CT の差異が同部で大きくなった ためだと考えられる。また，DSC はスライス位置に関 係なく大きく值が変化していることから, 評価指標の 中でも画像間の差異に敏感な指標だと考えられた。特 に腸管部でDSC の值が低下した，腸管はFDGの生 理的集積の程度, また症例間において一定ではないた め, pseudo_CT を生成するうえで最も困難な部位だ と考えており，これを反映した結果だと考える．差分 画像に挍いても腸管は残っており, DSC の結果を支持 していると考える. また, FDGの集積がない寝台や 頭部固定台も pseudo_CT では復元された. 教師画像 とした real_CT 上で一定の位置, 一定のピクセル值を 持って存在していたことから, 身体の一部として復元 されたと考えられる。

pseudo_CTにより減弱補正を行った pseudo_PET は, noac_PET と比べ身体深部のピクセル值の低下が 改善されており, 一応の目的は達成したと考えられ る.しかし, pseudo_CT と noac_PET 画像の構造上 のミスマッチから減弱補正にエラーが発生し, real_ PET ではみられない高集積様のアーチファクトが確 
認された。また，real_PETとの差分画像においても アーチファクトが差分されずに残る結果となった。こ のようなアーチファクトは偽陽性像として危険であ る。こういったミスマッチを減らすためには, pseudo_CT の作成精度を向上させるしかなく, モデルや データセット, ハイパーパラメータの更なる改善が必 要である。また，PET画像をべースにpseudo_CTを 作成していることから, pseudo_CTのピクセル值が $\mathrm{CT}$ 值ではないことも減弱補正の際にアーチファクト を生じさせる原因だと考えられる。各評価指標につい ても，noac_PETよりpseudo_PETは高值を示した。 ただし，前述のガイドラインのとおり，PSNRや SSIM の值は絶対的に高いわけではないため, 試料間 の相対的な值として捉える必要がある. SSIMについ ては，胸部から骨盤部で值が低下しており， pseudo_ CT 作成時に生じたreal_CT との差異が減弱補正に影 響したためと考えられる。また, SSIM とDSC では膀 胱部で值が極端に変化したが, これはピクセル值の大 きいピクセルが多いために起きた現象だと思われる。 DSC では，DSCを算出する過程で身体の領域を二值 化により分割したが，高ピクセル值を含むスライスで は二值化が困難な場合があり, DSC 算出に影響した可 能性がある。また, SSIM は計算式に平均ピクセル值 を用いるため, SSIM の局所的な上昇に寄与した可能 性がある。一方, PSNR はピクセル值の差を用いるた め高ピクセル值の影響が小さくなり，変化が小さかっ たと考えられる。したがって，こういった評価指標の 計算過程による差異を避けるためにも複数の類似評価 指標を用いる意義があると考えられる。

また, pseudo_CTに比べpseudo_PET の評価指標 の值は高くなった.PET 画像作成時, Q.Clear の $\beta$ は 650 としたが, 高い $\beta$ の設定による平滑化効果によっ て pseudo_PET の評価指標值が pseudo_CT に比べ高 くなったと考えられる。たたし, pseudo_CTで類似 指標が高いスライスで pseudo_PET の指標が高いわ けではなく, pseudo_CTの形状は復元できたが，ピク セル值までは完全に復元できていないと考えられ，さ らなる生成精度の向上を図る必要がある。

なお，本研究の環境下では，作成したモデルを用い た推定による pseudo_CT 画像生成から各種補正, お よび PET/CT 装置コンソール上での減弱補正適用ま で約 15 分を要した。この程度の作業時間であれば, 検査を妨げることなく実施可能だと考えられ，また， 装置コンソールに実装されれば，更に短時間で pseu-
do_PET 画像を取得できると考える。

他の症例についても pseudo_CT 画像を作成してモ デルの精度を検証したが，特徴的な症例だけを表記し た。多くの症例において, 歯冠は CT 画像のアーチ ファクトの原因となる。歯冠の影響のないPET 画像 から作成される pseudo_CTではアーチファクトの低 減が可能であり, 舌がんなどの口腔内疾患症例に有益 だ考えられる。また，pseudo_CTの利点として， $\mathrm{PET}$ と CT 画像とのミスレジストレーションを低減 できると考えている，例えば，呼吸性移動による影響 が大きい肝臓部の CT と PET 画像のフュージョン画 像は, pseudo_CTを用いることでミスレジストレー ションを低減できると考えられる。 pseudo_CTで表 現できない構造として，石灰化が挙げられる，石灰化 の有無が減弱補正に大きく影響する場面は少ないと考 えられるが, 考慮が必要である。また，FDGの特異的 な高集積症例にも注意が必要である。本研究で用いた 学習データは, FDGの異常集積がない症例を選択し て作成した。したがって, Fig. $8 \mathrm{c}$ に示すような症例に は学習結果をうまく反映できない. Figure 8d の無気 肺症例についても同様で, 学習用のデータセットから 大きく逸脱した集積や疾患をもつ症例には，本研究の 手法は適応できない，異常集積用の学習データセット を作成するなど，個々の対応が必要になると考えている.

\section{4. 結 語}

本研究では, 減弱補正を行っていないPET 画像か ら, 深層学習の画像生成モデルである GANを用いて 疑似的な CT 画像を作成し, これを PET 画像の減弱 補正に適用した。ハイパーパラメータの最適化や，偽 陽性と成り得るアーチファクトの発生, 特異的な症例 への対応など, いくつかの問題点が課題として残っ た。しかし, 疑似的な CT 画像により身体深部の信号 低下を改善し，また各評価指標も向上したことから， 当初の目的は達成したと考える。本研究の発展によ り，CTを撮影しない PET/CT 検査を実現すること で，患者被ばくの低減に寄与すると考える。

なお, 本研究の要旨は第 47 回日本放射線技術学会 秋季学術大会 (2019 年, 大阪)にて発表した。

\section{利益相反}

筆頭著者および共著者全員が開示すべき利益相反は ない. 


\section{参考文献}

1) Müller NL. Advances in imaging. Eur Respir J 2001; 18(5): 867-871.

2) Messa $C$, Bettinardi $V$, Picchio $M$, et al. PET/CT in diagnostic oncology. Q J Nucl Med Mol Imaging 2004; 48(2): 66-75.

3) Heiss WD, Rosenberg GA, Thiel A, et al. Neuroimaging in vascular cognitive impairment: a state-of-the-art review. BMC Med 2016; 14(1): 174-182.

4) Roland H, Ron JD, François B, et al. Impact of attenuation correction on the accuracy of FDG-PET in patients with abdominal tumors: a free-response ROC analysis. Eur J Nucl Med 2000; 27(9): 1365-1371.

5) Richard EC, Margaret EDW, Michael VG. A method for post injection PET transmission measurements with a rotating source. J Nucl Med 1988; 29(9): 1558-1567.

6) Xu EZ, Mullani NA, Gould KL, et al. A segmented attenuation correction for PET. J Nucl Med 1991; 32(1): 161-165.

7) Brush J, Boyd K, Chappell F, et al. The value of FDG positron emission tomography/computerized tomography (PET/CT) in pre-operative staging of colorectal cancer: a systematic review and economic evaluation. Health Technol Assess 2011; 15(35): 1-192.

8) Kwon HW, Kim JP, Lee HJ, et al. Radiation dose from wholebody F-18 fluorodeoxyglucose positron emission tomography/ computed tomography: nationwide survey in Korea. J Korean Med Sci 2016; 31(Suppl 1): S69-74

9）井上登美夫, 赤羽恵一, 池㴊秀治, 他. FDG-PET 検査に おける安全確保に関するガイドライン(2005 年).PET 検 査施設に扮ける放射線安全の確保に関する研究班 編。 2005.

10）森康久仁. 機械学習の基礎と医用画像への応用. 医用画 像情報会誌 2018; 35(3): 42-7.

11) 藤田広志。いま進化・多様化するコンピュー夕支援診 (断 (CAD)．医用画像情報会誌 2019; 36(2): 25-9.

12) Goodfellow I, Pouget-Abadie J, Mirza M, et al. Generative adversarial nets. In NIPS 27 proceedings 2014: 2672-2680.

13) Liu F, Jang H, Kijowski R, et al. A deep learning approach for 18F-FDG PET attenuation correction. EJNMMI Phys 2018; 5 (1): 24.

14) Hwang D, Kim KY, Kang SK, et al. Improving the accuracy of simultaneously reconstructed activity an attenuation correction maps using deep learning. J Nucl Med 2018; 59(10): 1624-
1629.

15) Liu F, Jang H, Kijowski R, et al. Deep learning MR imagingbased attenuation correction for PET/MR imaging. Radiology 2018; 286(2): 676-684.

16) Dong $X$, Wang $T$, Lei $Y$, et al. Synthetic CT generation from non-attenuation corrected PET images for whole-body PET imaging. Phys Med Biol 2019; 64(21): 215016.

17） Langr J, Bok V. はじめての GAN. 実践 GAN 一敵対的生 成ネットワークによる深層学習. 大和田 茂 訳. マイナ ビ出版, 東京, 2020: 3-7.

18) Isola $P, Z$ Zhu JY, Zhou $T$, et al. Image-to-image translation with conditional adversarial networks. In CVPR2017 conference proceedings 2017; 1: 5967-5976.

19) Mirza M, Osindero S. Conditional generative adversarial nets. arXiv preprint arXiv: $1411.1784 \mathrm{v} 1,2014$, https://arxiv.org/pdf/ 1411.1784.pdf.

20) Ledig C, Theis L, Huszar F, et al. Photo-realistic single image super-resolution using a generative adversarial network. arXiv preprint arXiv: 1609.04802v5, 2017, https://arxiv.org/pdf/1609. 04802.pdf.

21) Zhu JY, Park $T$, Isola $P$, et al. Unpaired image-to-image translation using cycle-consistent adversarial networks. In ICCV2017 conference proceedings 2017; 1: 2242-2251.

22) He $K$, Zhang $X$, Ren $S$, et al. Deep residual learning for image recognition. In CVPR2016 conference proceedings 2016; 1 : 770-778.

23) Wang Z, Bovik AC, Sheikh HR, et al. Image quality assessment: from error visibility to structural similarity. IEEE Trans Image Process 2004; 13(4): 600-612.

24) Otsu N. A threshold selection method from gray-level histograms. IEEE Trans Syst Man Cybern 1979; 9(1): 62-66.

25) Ioffe S, Szegedy C. Batch normalization: accelerating deep network training by reducing internal covariate shift. In: Bach FR, Blei DM (eds) ICML of JMLR workshop and conference proceedings 2015; 37: 448-456.

26) Metz L, Poole B, Pfau D, et al. Unrolled generative adversarial networks. arXiv preprint arXiv: 1611.02163v4, 2017, https:// arxiv.org/pdf/1611.02163.pdf.

27）小箱雅彦。標準化への道 標準化委員会報告(3) 電子化文 書の画像圧縮ガイドライン。月刊 IM 2011; 50(5): 21-24. 